\author{
LUDWIG STEINDORFF \\ Osteuropäische Geschichte \\ Historisches Seminar \\ Christian Albrechts-Universität zu Kiel \\ Kilonia, Niemcy
}

\title{
PRZESTRZENIE POSTRZEGANIA W TRAKCIE ZMIANY. ROZWAŻANIA O POJECCIACH EUROPA WSCHODNIA I EUROPA ŚRODKOWO-WSCHODNIA
}

Krótko przed przełomem 1989 r., jako asystent na wydziale historii Europy Wschodniej uniwersytetu w Münster odebrałem telefon od zarządu miasta Osnabrück. Planowano partnerstwo z Greifswaldem w Niemieckiej Republice Demokratycznej i potrzebowano informacji o historii tego miasta. Wydział historii Europy Wschodniej wydawał się trafnym adresatem zapytania. Wskazałem wtedy na specjalistów od historii Niemiec. Jak to zapytanie pięknie unaocznia, Europa Wschodnia była zrównywana ze światem państw socjalistycznych z NRD włącznie.

Z całkiem innym spojrzeniem zetknąłem się w 2010 r. na seminarium poświęconym kolonizacji miejskiej w pełnym średniowieczu, prowadzonym na moim uniwersytecie w Kilonii. Rozmawialiśmy o rozważaniach Klausa Zernacka zamykających tom konferencji Die deutsche Ostsiedlung $(1971)^{1}$. Na mą uwagę, że Zernack definiuje tutaj Europę Środkowo-Wschodnią jako szczególny obszar w obrębie Europy Wschodniej, który miał udział w kolonizacji na prawie niemieckim, zareagowała jedna polska doktorantka: ,Jak to Europa Środkowo-Wschodnia? Gdzie zatem jesteśmy my, Polacy? Jesteśmy Europą Środkową!". Na moje pytanie, czy zatem Niemcy należą do Europy Zachodniej, odpowiedziała - „Tak!”.

Naturalnie obie scenki nie są równoważne, ponieważ raz spotykamy się ze oglądem tego, co obce, a innym razem z oglądem tego, co własne. Rozmówczyni z Osnabrück chodziło o umiejscowienie tego, co

${ }^{1} \mathrm{~K}$. Zernack, Zusammenfassung: Die hochmittelalterliche Kolonisation in Ostmitteleuropa und ihre Stellung in der europäischen Geschichte, w: Die deutsche Ostsiedlung des Mittelalters als Problem der europäischen Geschichte. Reichenau-Vorträge 1970-1972, red. W. Schlesinger, Sigmaringen 1975, Vorträge und Forschungen 18, s. 783-804. 
obce, polskiej zaś doktorantce o własne umiejscowienie. Niezależnie od tego jednak zestawienie tych scen unaocznia zmianę, jaka dokonała się w toku minionych 23 lat. Europa Wschodnia jest częstokroć identyfikowana jeszcze tylko z państwami pozostałymi po ZSRR wyjąwszy państwa bałtyckie, w tym sensie Europa Środkowo-Wschodnia nie należy już do Europy Wschodniej. Po 40 latach wyraźnego wiązania Republiki Federalnej Niemiec z Zachodem i po transformacji nowych landów dokładnie według jej wzoru Niemcy stały się częścią Europy Zachodniej - to punkt widzenia powszechny, przynajmniej w starych landach.

Zmiana, jak i równie często trwałość mapy mentalnej (mental map), mapy w naszych głowach, były doświadczeniami towarzyszącymi mi stale w minionych ponad dwudziestu latach. Temat ten pojawia się także w sytuacjach codziennych: jak są posegregowane przewodniki w księgarni? Czy Słowenia i Polska należą tam do Europy Wschodniej? Przetłumaczona z języka angielskiego książka kucharska Osteuropäische Küche z 2002 r. ${ }^{2}$ przynosi przepisy dokładnie ze wszystkich dawnych państw socjalistycznych względnie z krajów będących ich sukcesorami. Brak tylko kuchni niemieckiej z byłej NRD. Natomiast w tytule książki kucharskiej Silveny Rowen „Europa Wschodnia” użyta jest w węższym sensie: The Eastern and Central European Kitchen ${ }^{3}$, „kuchnia wschodnio- i środkowoeuropejska”, przy czym „Central European” zastępuje tu „środkowo-wschodnioeuropejski” („ostmitteleuropäisch”) w obiegowym sensie tego słowa. Czytelnik nie znajdzie w książce żadnego przepisu z krajów Europy Południowo-Wschodniej.

Pod koniec lat dziewięćdziesiątych XX w. w łonie specjalizacji historii Wschodniej Europy doszło do intensywnej debaty. Czy specjalizacja powinna się rozwiązać? Czy ówczesna organizacja dyscypliny nie prowadzi wprost automatycznie do marginalizacji Europy Wschodniej w obrębie nauki historycznej? Czy z chwilą zakwestionowania historycznego obszaru Europy Wschodniej samookreślenie „historia Wschodniej Europy” nie staje się anachronizmem? Czy nie byłoby lepiej dla włączenia historii poszczególnych krajów z Europy Wschodniej do historii ogólnoeuropejskiej, gdyby profesury były przyporządkowane według specjalizacji poszczególnym epokom lub obszarom badawczym ${ }^{4}$

2 [K. Lisson], Osteuropäische Küche. Traditionelle Rezepte von der Ostsee bis zum Schwarzen Meer, Reichelsheim 2002 (oryg. ang. 1999).

${ }^{3}$ S. Rowen, The Eastern and Central European Kitchen: Contemporary \& Classic Recipes, London 2008.

${ }^{4}$ Inicjująca debatę rozprawa Jörga Baberowskiego i liczne odpowiedzi zostały potem zebrane w jednym tomie pod redakcją Stefana Creuzbergera Wohin steuert die Osteuropaforschung? Eine Diskussion, Köln 2000. 
Co wtedy uznawano za propozycję prowokacyjną i co było zdecydowanie odrzucane przez liczne koleżanki i wielu kolegów, teraz staje się niekiedy rzeczywistością: znajdujemy zatem czasem konkursy na stanowiska profesorskie w zakresie historii nowożytnej o specyfikacji „z naciskiem na historię Europy Wschodniej”. Albo koleżanki i koledzy historycy zajmujący się historią Europy Wschodniej powoływani są na profesury dla jednej określonej epoki. Granica między przedmiotem Europa Wschodnia a „powszechną" historią stała się z pewnością bardziej przepuszczalna.

Jako świadek rozwiązania Jugosławii dziwiłem się, jak długo trzeba było czekać, by ludzie w Niemczech na co dzień mówili już nie o Jugosławii, lecz o jej poszczególnych państwach sukcesyjnych. Obserwowałem, jak państwa, jakie z niej powstały, starały się o konsolidację swej tożsamości za pomocą polityki pamięci. W języku międzynarodowej polityki powstał nowy nadrzędny termin, który z jednej strony wyrażał akceptację dla rozwiązania Jugosławii, a z drugiej sugerował cechy wspólne: wszystkie państwa będące sukcesorami Jugosławii z wyjątkiem Słowenii tworzyły razem z Albanią „Zachodnie Bałkany”.

Temat mental map był wreszcie także przedmiotem kilońskiego podyplomowego kolegium „Imaginatio borealis”, z którym współpracowałem od 2002 r. do jego zamknięcia w 2008 r. Chodziło tutaj o analizę sposobów, jak geograficzna Północ bywa przedstawiana w tekstach historycznych i literackich lub w malarstwie, o to, jakie atrybuty przypisuje się Północy i jakimi środkami w różnych dziedzinach sztuki może być oznaczane coś jako „północne”, jakie znajdujemy granice Północy i w jakiej relacji względem innych kierunków geograficznych albo tego, co po prostu jest nie-Północą, może być ona postrzegana. Tematem kolegium było także zagadnienie,jak młode chrześcijańskie państwa „na Północy” - Polska czy Ruś Kijowska mogły rekompensować sobie niekorzystny brak związków z czasami apostołów w przeszłości ${ }^{5}$.

W 2005 r. w Berlinie jako, by tak rzec, test kontrolny towarzyszący debatom wokół umiejscowienia Europy Wschodniej i Południowo-Wschodniej odbyła się konferencja pt. „Der Süden Europas. Strukturraum Wahrnehmungsraum - Handlungsraum". Wprawdzie triada pojęciowa nie została ujęta w tytule tomu pokonferencyjnego ${ }^{6}$, a i w rozprawach

${ }^{5}$ L. Steindorff, Bilder vom Norden in der Geschichte Altrusslands, w: Norden und Nördlichkeit. Darstellungen vom Eigenen und Fremden, red. D. Hormuth, M. Schmidt, Frankfurt am Main 2010, Imaginatio borealis 21, s. 13-30; R. Michałowski, Ein Erzbistum im Norden gründen (wykład wygłoszony w czerwcu 2004 r. w Kolonii, poświęcony powstaniu arcybiskupstwa gnieźnieńskiego).

${ }^{6}$ Der Süden. Neue Perspektiven auf eine europäische Geschichtsregion, red. F. B. Schenk, M. Winkler, Frankfurt am Main 2007. 
znalazła zastosowanie tylko marginalne i bez systematyki, to jednak przeciwstawienie zwłaszcza dwu pierwszych pojęć wydaje mi się bardzo pomocne. Sam nawiązałem do nich niedawno, aby na spotkaniu poświęconym historii historiografii rosyjskiej w Paryżu prześledzić konsolidację terminu „rosyjska Północ” i związane z nim konotacje od połowy XIX w. aż do współczesności.

Zatem w moich niniejszych rozważaniach na temat terminów Europa Wschodnia i Europa Środkowo-Wschodnia rozpocznę od tych dwu pojęć. Pod pojęciem przestrzeni strukturalnej rozumiem, jak wskazuje słowo, przestrzeń, która wyróżnia się przez wspólne struktury, odnoszące się do stosunków społecznych, gospodarczych, politycznych bądź konfesyjnych. Im gęściejszy jest splot wspólnych struktur, im ściślej są rozbudowane formy komunikacji wewnątrz tej przestrzeni, tym mocniej przestrzeń strukturalna jest skonsolidowana. Przestrzeń strukturalna poddaje się obiektywizacji, jej istnienie daje się zweryfikować. Jej kształtowaniu się może sprzyjać przestrzeń naturalna, lecz jednocześnie jest ona w każdym przypadku stworzona przez człowieka. Nie musi jednak być jako taka „rozpoznana” i nazwana, należy ją odkryć, uświadomić sobie jej istnienie.

Odkrycie przestrzeni strukturalnej powoduje, że staje się ona jednocześnie subiektywną przestrzenią postrzegania, może otrzymać nazwę, w której odbijają się wiedza, doświadczenie i zamiary związane z tą przestrzenią.

Przestrzeń postrzegania jest więc konstruktem dyskursywnym. Przyswajająca percepcja przestrzeni może przejść w wyobraźnię tworzącą. Przestrzeń postrzegania może się pokrywać z przestrzenią strukturalną, lecz nie jest to konieczne. Przestrzeni postrzegania są przypisywane cechy charakterystyczne jako stereotypy, które mniej lub bardziej odpowiadać mogą stosunkom rzeczywistym, lecz nie muszą. Roszczenia do przestrzeni postrzegania mogą konkurować ze sobą i wzajemnie się wykluczać. Przestrzenie strukturalne mogą się przecinać bez kwestionowania adekwatności ich przyjęcia.

Gdy wychodzi się od tych dwu pojęć, to sposoby patrzenia Marii Todorovej z jednej strony i Holma Sundhaussena z drugiej okazują się wobec siebie nie przeciwne, lecz nawzajem się uzupełniające. Jak wskazuje tytuł książki Todorovej Imagining the Balkans ${ }^{7}$, chodzi jej o często nega-

${ }^{7}$ M. Todorova, Imagining the Balkans, New York 1997. Niemieckie tłumaczenie tytułu jest rozszerzone i negatywnie się kojarzy: eadem, Die Erfindung des Balkans. Europas bequemes Vorurteil, Darmstadt 1999. Na temat późnośredniowiecznego i wczesnonowożytnego obrazu Europy Południowo-Wschodniej por.: K. Petkov, Infidels, Turks, and Women. The South Slavs in the German Mind, ca.1400-1600, Frankfurt am Main 1997. 
tywne i upraszczające konotacje przestrzeni postrzegania „Bałkanów” z zachodnioeuropejskiego punktu widzenia. H. Sundhaussen w swoich licznych pracach na ten temat ma zupełnie inną intencję. Obszernie wywodzi, że adekwatne i obiecujące jest traktowanie Bałkanów jako historycznej przestrzeni strukturalnej ${ }^{8}$.

Tylko w nielicznych okresach historii Europa Wschodnia daje się ująć jako jedna naznaczona wieloma wspólnymi cechami przestrzeń strukturalna. Razem z Europą Północną Europa Wschodnia tworzy obszar, w którym etnogeneza, tworzenie się państw i chrystianizacja nastąpiły dopiero w pełnym średniowieczu ${ }^{9}$. Dlatego w oparciu o terminologię Oskara Haleckiego, który przeciwstawił starej Europie ukształtowanej przez wcześniejszą przynależność do Cesarstwa Rzymskiego nową Europę, K. Zernack w 1975 r. stwierdził: „Jest to poza- i pokarolińska nowa Europa. Razem z wprawdzie staroeuropejską, ale przez wczesnośredniowieczne tworzenie się narodów jako następstwo wielkich migracji barbarzyńskich na nowo ustrukturyzowaną bizantyńską Europą Południowo-Wschodnią tworzy przedmiot naszej dyscypliny"10.

Europa Wschodnia tworzy obszar „wtórnego poddaństwa” w Europie. Podczas gdy w Europie Zachodniej od późnego średniowiecza osobiste powiązania z panem włości stopniowo się rozluźniały, a na miejsce pańszczyzny wkraczały świadczenia w naturaliach i w końcu świadczenia pieniężne, proces ten we wczesnej nowożytności w Europie Wschodniej się odwrócił.

Europa Wschodnia to obszar wieloetnicznych i wielowyznaniowych imperiów wczesnej nowożytności - Rzeczypospolitej Obojga Narodów, Imperiów Rosyjskiego, Habsburskiego i Osmańskiego - a definiując wprost ex negativo - to ta część Europy, na której politycznej mapie z XVIII w. niemal nie zarysowują się dzisiejsze podziały terytorialne. Zaledwie kilka dawnych linii granicznych służy i dziś jako granice,

${ }^{8}$ Por. np. H. Sundhaussen, Der Balkan. Ein Plädoyer für Differenz, „Geschichte und Gesellschaft. Zeitschrift für Historische Sozialwissenschaft" 29, 2003, 4, s. 608-624.

${ }^{9}$ Por. L. Steindorff, Die Christianisierung des östlichen Europa. Ein Schritt zur Integration, w: Geschichte und Geschichtsvermittlung. Festschrift für Karl Heinrich Pohl, red. O. Hartung, K. Köhr, Bielefeld 2008, s. 27-40.

10 „Es ist das außer- und nachkarolingische Neueuropa. Zusammen mit dem zwar alteuropäischen, aber durch die frühmittelalterliche Nationsbildung - als Folge der großen Barbaren-Migrationen - neustrukturierten byzantinischen Südosteuropa bildet den Gegenstand unseres Faches", K. Zernack, Osteuropa. Eine Einführung in seine Geschichte, München 1977, s. 27. Ponieważ w myśl definicji Haleckiego cała Europa Południowo-Wschodnia, nawet jeśli nie z tą samą intensywnością naznaczona wcześniejszą przynależnością do Cesarstwa Rzymskiego, należy do starej Europy, można by słowo „bizantyński” w zdaniu tym skreślić. 
wśród nich granica czesko-słowacka lub granica między Chorwacją i Bośnią-Hercegowiną.

Przede wszystkim jednak po II wojnie światowej ponad wszystkimi wariantami wprowadzania systemu przez socjalistyczny model państwa, gospodarki i społeczeństwa wytworzyła się wspólna przestrzeń strukturalna, która oddziałuje także po końcu systemu socjalistycznego, aż do współczesności.

Jednakże cechy wspólne w wielu okresach znajdują się w cieniu takich różnicujących cech, jak język, etnos, podział na państwa, a przede wszystkim religia bądź wyznanie. Jako przestrzeń strukturalna jednostka o nazwie „Europa Wschodnia” pozostaje słabo zakotwiczona ${ }^{11}$.

W przeciwieństwie do tego Europa Środkowo-Wschodnia tworzy o wiele stabilniejszą historyczną przestrzeń strukturalną. Została schrystianizowana z Zachodu, z Rzeszy. Rozwijała się tutaj średniowieczna kolonizacja wiejska i miejska na prawie niemieckim - od wschodniego Holsztynu aż do Galicji, od Bałtyku po Siedmiogród czy północną Chorwację. Cała Europa Środkowo-Wschodnia została wprawdzie objęta przez reformację, lecz w końcu wszędzie w toku kontrreformacji katolicyzm zdobył sobie pozycję wyznania jednoznacznie dominującego. Europa Środkowo-Wschodnia pozostaje mimo to obszarem różnorodności etnicznej i religijnej, której kres nadszedł w znacznym stopniu dopiero z II wojną światową. Jest obszarem, na którym we wczesnej nowożytności, w najbardziej wyrazisty sposób w Rzeczypospolitej Obojga Narodów, stany wywalczyły sobie mocną względem władzy królewskiej pozycję. Europa Środkowo-Wschodnia od późnego średniowiecza aż po Holokaust była centrum żydowskiego życia w Europie. Wytworzenie porządku państwowo-narodowego nastąpiło - nawiązując do już od dawna skonsolidowanych narodów kulturowych - w drodze rozpadu imperiów w następstwie I wojny światowej.

Opisywana w kategoriach granic państwowych przestrzeń strukturalna Europy Środkowo-Wschodniej daje się o wiele lepiej określić na podstawie mapy Europy z XVIII w. z granicami sprzed rozbiorów Polski niż na bazie granic współczesnych. Niektóre z dzisiejszych państw, których przynajmniej część obszarów wykazuje cechy typowe dla Europy Środkowo-Wschodniej, z innych punktów widzenia dają się przyporządkować także Europie Południowo-Wschodniej - mianowicie Węgry, Chorwacja, Serbia i Rumunia. Jednocześnie Ukraina i Białoruś należą do Europy Wschodniej w węższym sensie.

${ }^{11}$ Można to również językowo uwypuklić: w języku polskim Europa Wschodnia i wschodnia Europa, w języku niemieckim Osteuropa albo östliches Europa. Pierwsze wyrażenie implikuje jakąś przestrzeń strukturalną, drugie wskazuje na położenie geograficzne. 
Gdy spogląda się na przynależność Europy Środkowo-Wschodniej do obszaru Kościołów zachodnich, przede wszystkim katolicyzmu, gdy wyjdzie się z założenia, że należy ona do obszaru średniowiecznego kształtowania się gmin miejskich i rozwoju systemu stanowego, to można widzieć Europę Środkowo-Wschodnią w położeniu peryferyjnym na wschodnim krańcu tego obszaru - jako antemurale christianitatis, jak to pozytywnie ujmowano we wczesnonowożytnej perspektywie własnej.

Ze względu na peryferyjne położenie i opóźniony rozwój w obrębie całego obszaru Kościołów zachodnich Europę Środkowo-Wschodnią można w pełni porównać z Europą Północną lub takimi krajami, jak Szkocja czy Irlandia. Te ostatnie mają za sobą tylko morze i dalekie kraje po drugiej jego stronie. Natomiast Europa Środkowo-Wschodnia stykała się ze światem prawosławnym, a we wczesnej nowożytności także muzułmańskim. Liczne komplikacje, począwszy od będącej częściowym sukcesem kościelnej unii brzeskiej z 1596 r., spowodowała przede wszystkim późnośredniowieczno-wczesnonowożytna ekspansja państwa polsko-litewskiego w kierunku należących wcześniej do Rusi Kijowskiej terytoriów naznaczonych obecnością prawosławia. Można więc mówić zarówno o położeniu peryferyjnym, jak i o pomostowym.

Możemy w końcu spytać, czy w historii spotykamy się także z Europą Środkowo-Wschodnią jako przestrzenią działania (Handlungsraum), jako przestrzenią zintensyfikowanej komunikacji między aktorami, jako „sceną" dziania się, niezależną od zastanych cech strukturalnych. Impuls do powstania przestrzeni działania może nadejść zarówno z wewnątrz, jak i z zewnątrz. Poczynania późnośredniowiecznych dynastii Andegawenów, Luksemburgów albo Jagiellonów powodują wyłonienie się w XIVXV w. Europy Środkowo-Wschodniej jako wspólnego obszaru politycznego działania ${ }^{12}$. Nazwana tak przez Zernacka „,negatywna polityka polska" Cesarstwa Rosyjskiego i Prus spowodowała przekształcenie Rzeczypospolitej szlacheckiej w przestrzeń działania dla obu sąsiednich państw.

Wreszcie niedawno przez Timothy'ego Snydera opisana przestrzeń działania „Bloodlands” pokrywa się niestety całkiem dokładnie z Europą Środkowo-Wschodnią z włączeniem Ukrainy i Białorusi ${ }^{13}$. Wrażenie

${ }^{12}$ By sparafrazować tytuł pokonferencyjnego tomu pod redakcją Marca Löwenera Die „Blüte” der Staaten im östlichen Europa im 14. Jahrhundert (Wiesbaden 2004, Deutsches Historisches Institut Warschau. Quellen und Studien, 14), był to „rozkwit imperiów w Europie Środkowo-Wschodniej”. Omawiane w tym tomie państwo moskiewskie wypada z ram tematycznych o tyle, że wiek XIV stanowi dla niego raczej czas nowego początku.

${ }^{13}$ T. Snyder, Bloodlands. Europe Between Hitler and Stalin, London 2010, i nowsze wydania; przekład niemiecki z angielskim słowem w tytule: idem, Bloodlands. Europa unter Hitler und Stalin, München 2010. 
wzmaga się jeszcze dzięki mapom do oznaczenia „skrwawionych ziem”14. „Bloodlands” powstały z fali straszliwej przemocy, którą zainicjowały posługujące się terrorem reżimy narodowego socjalizmu i stalinizmu i która wzięła się z czasowej współpracy jak również konfrontacji III Rzeszy i Związku Sowieckiego za Stalina. O ile ustalenia Snydera mogą być trafne, o tyle irytująca jest jednakże plakatowa metonimia „Bloodlands”, tak jak gdyby obszar ten był od dawna predestynowany do tego wydarzenia i przez nie na zawsze napiętnowany.

W niniejszym wywodzie powinno chodzić o historię przestrzeni postrzegania Europy Wschodniej i Europy Środkowo-Wschodniej, czyli także o „odkrycie” tych ledwo zarysowanych przestrzeni strukturalnych.Jak Larry Wolff dowiódł obszernie w swojej książce Inventing the Eastern Europe, wykształcenie się negatywnie konotowanego obrazu ówczesnych państw Europy Wschodniej, w tym Rzeczypospolitej Obojga Narodów, sięga XVIII w., jednakże bez przebicia się terminu Europa Wschodnia do określenia tego obszaru $^{15}$. Termin Europa Wschodnia zakorzenił się dopiero równolegle z przesunięciem Rosji na mapie mentalnej - w obcej,jak i własnej perspektywie - z kraju Północy do kraju na Wschodzie ${ }^{16}$. Aż do czasu I wojny światowej Europa Wschodnia pokrywała się szeroko z europejskim obszarem ówczesnego Cesarstwa Rosyjskiego z Królestwem Kongresowym włącznie, jak to daje się poznać po ówczesnym rozumieniu misji założonego w $1902 \mathrm{r}$. pierwszego Seminarium Europy Wschodniej (Seminar für Osteuropäische Geschichte). Niemieckie Towarzystwo Badań Europy Wschodniej (Deutsche Gesellschaft für Osteuropakunde) nosi tę nazwę dopiero od 1918 r., lecz założone zostało jeszcze w 1913 r. pod nazwą Niemieckiego Towarzystwa Studiów nad Rosją (Deutsche Gesellschaft zum Studium Russlands).

W okresie międzywojennym spotykamy się z takim rozumieniem Europy Wschodniej, zgodnie z którym Europa Południowo-Wschodnia jawi się jako subregion Europy Wschodniej, co na przykład pięknie unaocznia tytuł wydanej w 1930 r. przez Maxa Seringa zbiorowej pracy Die agrarischen Umwälzungen im außerrussischen Osteuropa ${ }^{17}$. Tom obejmuje artykuły na temat wszystkich krajów, które zgodnie z dziś w Niemczech funkcjo-

${ }^{14}$ Np. mapa w omówieniu Timothyego Nunana, A Journey to Timothy Snyder's „Bloodlands”, tekst dostępny pod adresem 〈http://timothynunan.com/2011/06/04/ a-journey-to-timothy-snyders-bloodlands/ $\rangle$ (dostęp: 26 VI 2012).

${ }^{15} \mathrm{~L}$. Wolf, Inventing Eastern Europe. The Map of Civilisation on the Mind of the Enlightenment, Stanford 1994.

${ }^{16} \mathrm{O}$ tym procesie por. H. Lemberg, Zur Entstehung des Osteuropabegriffs im 19. Jahrhundert. Vom „Norden“ zum „Osten“ Europas, „Jahrbücher für Geschichte Osteuropas” 33, 1985, s. 48-91.

${ }^{17}$ Die agrarischen Umwälzungen im außerrussischen Osteuropa. Ein Sammelwerk, red. M. Sering, Berlin-Leipzig 1930. 
nującym podziałem należą do Europy Północno-Wschodniej (Finlandia i kraje bałtyckie), Europy Środkowo-Wschodniej lub Europy Południowo-Wschodniej, a czasami są obejmowane wspólnym nieszczęsnym mianem Międzyeuropy (Zwischeneuropa).

Żelazna kurtyna i powstanie świata państw socjalistycznych w Europie doprowadziły następnie do tego, że przestrzeń postrzegania i przestrzeń strukturalna Europy Wschodniej stopniowo się pokrywały. Procesowi temu w Republice Federalnej Niemiec towarzyszyła instytucjonalizacja międzydyscyplinarnych badań nad Europą Wschodnią, jak i subdyscypliny o nazwie historia Europy Środkowo-Wschodniej ${ }^{18}$. Dwa czynniki wspierały powstanie historycznej subdyscypliny: $z$ jednej strony było to zainteresowanie obszarem postrzeganym jako inny i dążenie, by wzmacniać to, co własne, poprzez ogląd tego, co inne. $Z$ drugiej strony tendencja do wewnętrznej specjalizacji w obrębie nauk historycznych przyczyniła się do konsolidacji subdyscypliny historii Europy Środkowo-Wschodniej, ponieważ wymagano tu szczególnych zdolności i umiejętności, związanych z kompetencjami językowymi.

Jednocześnie jednak ciągle żywe było w tle pytanie o doniosłość przestrzeni postrzegania Europy Wschodniej. Czy rzeczywiście wspólne dla całej Europy Wschodniej cechy strukturalne były mocniejsze niż wewnętrzne zróżnicowania? Ciągle istniało rozcięcie między „wąsko rozumianą" Europą Wschodnią, która pokrywała się z Rosją względnie Związkiem Radzieckim bez republik bałtyckich, i Europą Wschodnią szerzej rozumianą. Europie Wschodniej w węższym znaczeniu tego słowa przeciwstawił O. Halecki w 1952 r. swoją książkę Borderlands of Western Civilization. A History of East Central Europe. Tytuł jej niemieckiego wydania z 1956 r., Grenzraum des Abendlandes. Eine Geschichte Ostmitteleuropas, ma niezupełnie ten sam sens. Niesie o wiele mocniejsze skojarzenia z religijnymi aspektami odgraniczenia wobec świata prawosławnego i islamskiego. W każdym razie pojęcie „East Central Europe” względnie „Europa Środkowo-Wschodnia" obejmuje tutaj także Europę Środkowo-Wschodnią w sensie nam najbardziej znajomym, czyli także Europę Północno-Wschodnią i całą Europę Południowo-Wschodnią, a zatem obszary, które są ukształtowane pod wpływem prawosławia bądź częściowo nawet islamu. Kwestia, czy ten „obszar graniczny” należy do cywilizacji zachodniej względnie do Zachodu albo czy stanowi jego szaniec, pozostanie

${ }^{18}$ Jako bilanse cząstkowe instytucjonalnej historii tego przedmiotu służą tomy: Geschichte Osteuropas. Geschichte einer Disziplin im deutschen Sprachraum 1945-1990, red. E. Oberländer, Stuttgart 1992, Quellen und Studien zur Geschichte des östlichen Europa, 35; Hundert Jahre Osteuropäische Geschichte. Vergangenheit, Gegenwart, Zukunft, red. D. Dahlmann, Stuttgart 2005, Quellen und Studien zur Geschichte des östlichen Europa, 68. 
w tym przedstawieniu ostatecznie otwarta, w każdym razie nie należy on do Wschodu.

Prawdopodobnie niegdysiejszemu czytelnikowi to umykało, ale słowo końcowe K. Zernacka w tomie pokonferencyjnym Die deutsche Ostsiedlung daje się czytać wprost jako namiętna obrona wyodrębnienia Europy Środkowo-Wschodniej jako szczególnego obszaru w obrębie Europy Wschodniej ${ }^{19}$. Intencją Zernacka wydaje się tu wypracowanie historycznego powiązania z Europą Środkową i Zachodnią niezależnego od aktualnych stosunków politycznych. Systematycznie rozwinął te idee w swej porównawczej historii Polski i Rosji ${ }^{20}$.

Podobnie jak u Haleckiego, i u Jenő Szücsa w jego dziele z 1983 r. środkowy z ,trzech historycznych regionów Europy” obejmuje na równi Europę Środkowo-Wschodnią i Europę Południowo-Wschodnią.Jednakowoż Szücs podkreśla zarazem samodzielność środkowego regionu wobec zachodniego i precyzuje granicę między nimi oboma, zauważając, że przebieg żelaznej kurtyny pokrywa się ze wschodnią granicą królestwa Karolingów, jak i zachodnią granicą wczesnonowożytnego władztwa gruntowego ${ }^{21}$.

Natomiast debata o Środkowej Europie (Mitteleuropa-Debatte) w latach osiemdziesiątych wychodziła z założenia, które wyłączało Europę Południowo-Wschodnią, a przynajmniej terytoria poza dawną monarchią Habsburgów ${ }^{22}$. Skupiała się na wspólnych zjawiskach, które można było znaleźć po tej i tamtej stronie żelaznej kurtyny w historycznie zakorzenionych cechach strukturalnych, jak i w aktualnych interesach społecznych. Podczas gdy Europa Wschodnia jako taka definiowana jest z zewnątrz i prawdopodobnie nikt z Europy Środkowo-Wschodniej nigdy nie nazwałby siebie „Wschodnioeuropejczykiem”, terminy Europa Środkowa, jak i Europa Środkowo-Wschodnia odpowiadają własnemu oglądowi z wewnątrz.

W debacie tej możemy widzieć odprysk „konserwatywnych lat osiemdziesiątych"23, kiedy to - jak sądzono - obserwowano, jak złagodniałe

${ }^{19}$ K. Zernack, Zusammenfassung, s. 783-804.

${ }^{20}$ Idem, Polen und Rußland. Zwei Wege in der europäischen Geschichte, Berlin 1994, Propyläen-Geschichte Europas. Ergänzungsband.

${ }^{21}$ J. Szücs, Die drei historischen Regionen Europas, Frankfurt 1990 (oryg. węg. 1983), s. 13, 15. Z ponownym zjednoczeniem Niemiec w 1990 r., to jest z chwilą zniesienia granicy, fascynacja tym spostrzeżeniem straciła znacznie na sile.

22 Do debaty o Europie Środkowej odnosił się wielokrotnie mój ówczesny Kolega z Kilonii Rudolf Jaworski, np. idem, Die aktuelle Mitteleuropadiskussion in historischer Perspektive, „Historische Zeitschrift” 247, 1988, s. 529-550, przedruk w: Ostmitteleuropa im Fokus. Ausgewählte Aufsätze von Rudolf Jaworski, red. E. Hübner, M. Niendorf, H.-Ch. Petersen, Osnabrück 2009, s. 97-116.

${ }^{23}$ Termin zapożyczony od Riho Altnurme, Die Phase des Zusammenbruches der kom- 
z wiekiem reżimy dopuszczają wolną przestrzeń dla nowych dyskursów. Dopiero poniewczasie rozpoznano owe dyskursy jako delegitymizację starego reżimu i zapowiedź przełomu. Należały do nich historyczny namysł nad przeszłością, ,rehabilitacja” Austro-Węgier, zaznaczenie tego, co własne, w opozycji do Związku Radzieckiego przy jednoczesnym poszukiwaniu tego, co wspólne z sąsiadami po tej i tamtej stronie żelaznej kurtyny. Debata o Europie Środkowej wychodziła z założenia o możliwości „trzeciej drogi" między zachodnim i socjalistycznym modelem gospodarczym. Postulowała powstanie neutralnego obszaru w Europie.

Za polityczne ukoronowanie renesansu Środowo-(Wschodniej) Europy można uznać moment, gdy Polska, Węgry i ówczesna Czechosłowacja w dniu 15 lutego 1991 r., czyli jeszcze przed rozwiązaniem Układu Warszawskiego i upadkiem Związku Radzieckiego, utworzyły Grupę Wyszehradzką. W akcie założycielskim definiowały się explicite jako Europa Środkowa. Jako swój cel ogłosiły obok demokratyzacji zgodnej z modelem zachodnim przejście do gospodarki rynkowej i udziału w europejskiej integracji, rozumianej jako procesy integracyjne wychodzące z Zachodu. Jednakże w tym czasie trudno jeszcze było wyobrazić sobie, jak daleko zajdzie ostatecznie integracja z Zachodem byłych państw satelickich ZSRR, tak że nawet byłe republiki radzieckie, mianowicie kraje bałtyckie, będą mogły stać się członkami NATO i Unii Europejskiej.

Wkrótce jednak spojrzenia na siebie jako Europę Środkową czy też Europę Środkowo-Wschodnią zostały wyparte: zbyt różnorodne były linie rozwojowe i problemy w poszczególnych państwach, począwszy od rozwiązania Czechosłowacji. Każde państwo dążyło do uzyskania dla siebie możliwie najszybszej drogi integracji z Zachodem. Ponad wspólnymi cechami większych regionów poszczególne państwa narodowe utworzyły silnie oddziałujące przestrzenie strukturalne. Ważniejsze od wstąpienia Polski, Czech i Węgier do NATO w 1999 r., Słowacji w 2004 r. - równocześnie z państwami bałtyckimi, Rumunią i Bułgarią - było jednoczesne wstąpienie do UE łącznie z państwami bałtyckimi i Słowenią. Wraz z niewybraniem „trzeciej drogi”, w tym - niepowstaniem neutralnego obsza$\mathrm{ru}, \mathrm{z}$ transformacją rozumianą jedynie jako dorównanie do wzorów zachodnich sąsiadów, z udaną integracją z Zachodem w debacie o Europie Środkowej odniesienie do aktualnych politycznych i społecznych uwarunkowań straciło bardzo na znaczeniu.

munistischen Herrschaft in Estland, Lettland und Litauen, w: Wie die Träumenden? Protestantische Kirchen in der Phase des Zusammenbruches der kommunistischen Herrschaft im östlichen Europa, red. P. Maser, J. H. Schjørring, Erlangen 2003, s. 63-76, tu s. 64. 
Europa Środkowo-Wschodnia jest dla odmiany nadal obecna w Niemczech jako relatywnie otwarte pojęcie strukturalne nauki historycznej,jak również jako przestrzeń postrzegania. Do zakotwiczenia się pojęcia przyczyniło się w decydujący sposób założenie w 1995 r. w Lipsku Geisteswissenschaftliches Zentrum Ostmitteleuropa. Instytucja ta skoncentrowana jest na badaniach historycznych, które bazują na fakcie istnienia przestrzeni strukturalnej Europy Środkowo-Wschodniej. Wydawany przez marburski Instytut Herdera periodyk „Zeitschrift für Ostforschung” w swej treści już długo przed przełomem uwolnił się od ograniczeń ideologicznych niemieckiego „badania Wschodu” (Ostforschung), w 1994 r. uczynił to jeszcze dodatkowo przez zmianę tytułu na „Zeitschrift für Ostmitteleuropa-Forschung", bez konieczności zmiany skrótu Zfo.

W ramach powyższych rozważań nawiązałem do niemal wszystkich pytań z zestawu w zaproszeniu do współpracy przy zeszycie tematycznym „Kwartalnika Historycznego”, poza pierwszym pytaniem. Czy regionalne podziały mają w ogóle sens jako schemat konceptualny dla historyka? Nawet gdybyśmy w to wątpili, musimy uznać jako wręcz antropologiczną stałą, że jednostki i grupy porządkują przestrzennie swe postrzeganie świata i nadając nazwy poszczególnym obszarom, wychodzą od kierunków geograficznych i relacji do innych terytoriów. Uprawnionym więc postulatem nauki historycznej jest towarzyszyć temu zjawisku i je współkształtować, oczywiście jak długo cel poznania nie będzie polegał na legitymizowaniu ekskluzji i dyskryminacji. Nawet jeśli przestrzeń sama nie jest przedmiotem historiograficznego projektu, to jest niemal wykluczone mówienie o historycznych wydarzeniach i procesach bez uwzględniania przestrzeni w opisie jako wielkości referencyjnej.

Czy Polska należy do Europy Wschodniej w szerszym sensie, czy Polska z niemieckiej perspektywy zalicza się do Europy Środkowo-Wschodniej, czy Polska siebie samą identyfikuje jako Europa Środkowa - nie musimy tych pytań rozstrzygać. Zależnie od kontekstu narzucają się różnorodne odpowiedzi z wewnętrznego, jak i zewnętrznego punktu widzenia. Ważne jest przede wszystkim, by jeszcze nie do końca podniesiona żelazna kurtyna zniknęła szybko i bez śladu z naszych głów, byśmy nie traktowali różnic jako uzasadnienia oddzielenia, abyśmy przeżywali je raczej jako różnorodność we wspólnocie.

Zjęz. niemieckiego przełożył Bartosz Kaliski 